Article

\title{
Reprioritising Sustainable Development Goals in the Post-COVID-19 Global Context: Will a Mandatory Corporate Social Responsibility Regime Help?
}

\author{
Rajiv Nair ${ }^{1}\left(\mathbb{D}\right.$, P.K Viswanathan ${ }^{1, *(1)}$ and Bettina Lynda Bastian ${ }^{2}(\mathbb{D})$ \\ 1 Department of Management, Amrita Vishwa Vidyapeetham, Amritapuri, Kollam 690525, India; \\ rajivnair@am.amrita.edu \\ 2 USEK Business School, Holy Spirit University of Kaslik, Jounieh 1200, Lebanon; \\ bettinalyndabastian@usek.edu.lb \\ * Correspondence: pkviswam@gmail.com
}

Citation: Nair, Rajiv, P.K

Viswanathan, and Bettina Lynda Bastian. 2021. Reprioritising Sustainable Development Goals in the Post-COVID-19 Global Context: Will a Mandatory Corporate Social Responsibility Regime Help?

Administrative Sciences 11: 150. https: / / doi.org/10.3390/ admsci11040150

Received: 22 September 2021 Accepted: 30 November 2021 Published: 8 December 2021

Publisher's Note: MDPI stays neutral with regard to jurisdictional claims in published maps and institutional affiliations.

Copyright: (c) 2021 by the authors. Licensee MDPI, Basel, Switzerland. This article is an open access article distributed under the terms and conditions of the Creative Commons Attribution (CC BY) license (https:// creativecommons.org/licenses/by/ $4.0 /)$.

\begin{abstract}
The impact of COVID-19 on the United Nations Sustainable Development Goals (SDGs) continues to be researched. Initial signals warn of significant setbacks in achieving SDG targets by 2030 . The achievement of SDGs could abet improved protection from future pandemics. This article suggests reprioritizing SDGs to facilitate a more robust global response to future pandemics. Specifically, we recommend that SDGs 3, 6, 5 and 4 (in that order) are prioritized in order to optimize efforts at a more inclusive and resilient socio-economic recovery post-pandemic. This paper suggests that mandatory CSR regimes enable governments, in combination with corporate fiscal resources, to influence the selection and progress of these SDGs. The case of India's mandatory CSR regime is employed to illustrate our position. This study extends the debate on SDGs by raising the possibility of universal concentration on a few critical SDGs.
\end{abstract}

Keywords: COVID-19; coronavirus disease; SDG; sustainable development goals; CSR; corporate social responsibility

\section{Introduction}

The 2030 Sustainable Development Goals (SDGs) were framed and adopted in 2015 by member states of the United Nations (UN). SDGs were evolved from the Millennium Development Goals (MDGs) to further address the targets left unfulfilled by the MDGs (Kumar et al. 2016) and are envisioned as the culmination of a long history of efforts by member nations and the UN departments ${ }^{1}$. SDGs are a set of targets that can broadly be grouped into five categories: People, Prosperity, Planet, Peace and Partnerships (Bhowmick 2020, see Appendix A). Each category comprises multiple goals, which are further broken down into specific targets to be achieved by 2030. Despite their laudable objectives, the UN SDGs are not without criticisms. For example, Kopnina (2016) contends that SDGs may in fact lead to unsustainable practices in developing economies. Kopnina's (2016) misgivings appear to be well founded considering South Asia's comparatively slow progress in achieving the SDGs.

The efforts of national governments, NGOs and corporations towards achieving SDGs were abruptly interrupted by the COVID-19 pandemic. Though the 17 SDGs were framed in a pre-COVID-19 setting, they appear to be more relevant post-COVID-19, as there is a high likelihood that the lessons from the crisis will be forgotten and society will revert to its old behavioral patterns. Bhowmick (2020) opines that the SDGs will have renewed relevance in a post COVID-19 world because the main forms of capital (human, social, physical and environmental) are embedded in and interlinked with the SDGs. Shah (2020) warns that reverting to old business models risks the recurrence of similar pandemics and other global crises. Arguably, this is not an unreasonable expectation, especially in 
developing markets where traditions and indigenous beliefs have deep roots. Numerous commentaries expound the severe impacts of COVID-19 on the SDGs. Some elucidate the increased relevance of SDGs in a post-COVID-19 environment (Solberg and Akufo-Addo 2020; Lu 2020), while others (e.g., Bhowmick 2020) discuss the possibility that COVID-19 may impede the realization of the SDGs. The United Nations Department for Economic and Social Affairs (UNDESA) provides a sector-wide mapping of potential implications of COVID-19 on the SDGs (UNDESA 2020). Sabu (2020) observes that the pandemic-led rise in unemployment and disruption in global supply chains has increased poverty and hunger severely.

Moreover, the second wave of the pandemic posed more serious concerns about the successful accomplishment of the critical SDGs relating to health and well-being (SDG 3) and water and sanitation (SDG 6). In India, for instance, the healthcare systems in many parts of the country were significantly disrupted in the second wave, which lasted February-June 2021. Reportedly, the second wave of the pandemic had resulted in a chaotic situation in India, with public healthcare institutions failing to manage the crisis. The consequence has been a sharp rise in death tolls caused by the shortage of ventilators, oxygen supplies, ICU beds and a lack of critical care units (CCUs) in hospitals. Despite commendable efforts by the state, non-government organizations (NGOs), corporates and other civil society organizations, the first wave had already exposed the shortcomings of health infrastructure and health services across states in the country.

Thus, financing and fast tracking the achievement of the critical goals, especially those related to health and well-being, within the original deadlines, pose a significant challenge for many developing economies, including India. Shah (2020) argues that SDGs need to be weaved into economic recovery plans. Addressing the socio-economic impact of COVID-19, the UN Secretary General posited that globally coordinated responses will have a significant role in reducing social inequalities exposed by the pandemic (UN 2020c). One potential source of finance, in the fight against the pandemic, is the corporate social responsibility (CSR) funds in various countries. He and Harris (2020) speculate that the financial stress induced by the pandemic could either lead companies to focus on shortterm survival and eschew CSR or respond to the new normal with increased CSR activities. Available evidence indicates that the latter postulate of He and Harris (2020) seems to have prevailed, with businesses across the world having contributed to the vast funds in the fight against the virus (World Economic Forum 2020; IICA 2020). For instance, following the Indian government's decision to treat anti-COVID-19 measures of firms as CSR (Singh 2020), approximately USD $1545^{2}$ million was allocated to such projects (CRISIL 2020).

Against this backdrop of searching for alternate models of financing and fast tracking the achievement of the SDGs, the present paper makes a case for devising long-term strategies and action plans for linking the SDGs with CSR regimes in the post-pandemic global context, with an emphasis on reprioritizing SDGs 1-6 (People). Tsalis et al. (2020) provide evidence of prior research that encourages the linking SDGs to CSR. We argue that mandatory CSR regimes better facilitate the achievement of SDGs than do voluntary CSR regimes. As an illustrative case, the current paper studies the SDG-CSR links in India. We choose India since it is the first country to mandate CSR across industries. The Indian Companies Act (2013) mandates that firms meeting a set of criteria earmarks $2 \%$ of the average net profit from the preceding three years towards CSR. The mandate prescribes activities that qualify as CSR and also specifies the format for disclosure.

Following this introductory section, the next section explores the potential linkages between CSR activities and SDGs in the emerging global context. The section then presents a case analysis of the mandatory CSR regime being implemented in India since 2013 and its linkages with the SDGs. In Section 3, we present a case for devising long-term strategies and action plans for linking the SDGs with CSR regimes in the post-pandemic global context, with an emphasis on reprioritizing SDGs 1-6. Section 4 concludes and suggests areas for further research, policy interventions and actions. 


\section{CSR-SDG Linkages: An Exploration}

SDGs have been criticized as being sourced in a Western, economic and modernist perspective (e.g., Kopnina 2016; Regmi and Walter 2017). These critics contend that SDGs do not necessarily align with the socio-cultural and economic fabric of non-Western, less developed nations. Thus, according to its critics, SDGs are most likely to disrupt sustainable practices, if not fail entirely. Regmi and Walter (2017) observe that SDGs advocate abandoning traditional beliefs and practices due to a presumption that modern methods will deliver sustainability. Furthermore, Cohen and Cohen (2015) and Pieterse (1996) fault the ethnocentric approach of modernist theory, which leads to the imposition of Western ontological beliefs on non-Western nations. It can thus be inferred that while SDGs in themselves are noble objectives, adopting a cookie-cutter method to achieve them could be sub-optimal. Thus, implementers of SDG programs would need to adopt measures that align with the local environment and society. Osuji and Nwani (2020) hold that a public-private partnership is necessary for favorable SDG outcomes. Considering the financial and logistical wherewithal required to implement and carry out plans to achieve SDGs, it is not far-fetched to envisage a role for business firms in such an endeavor.

This rationale especially applies in contexts characterized by institutional voids (Palepu and Khanna 1998), where institutions are weak or absent and thus fail to fulfil their missions (Mair and Marti 2009). In such environments, as often present in emerging contexts, companies with capabilities and resources can be useful to address certain gaps-sometimes it even helps them to generate a competitive advantage in markets, since not all firms possess the same capabilities and resources (Doh et al. 2017); sometimes it also provides firms with institutional shields (Amaeshi et al. 2016) that protect their interests in weak institutional settings. Previous research reveals how firms can be useful when developing responsible business practices that support important causes for society and allow for new institutions to be created, which fill institutional voids by substituting state activities (Amaeshi et al. 2016; Lepoutre and Valente 2012), as well as by building necessary infrastructures and services for society (Banerjee et al. 2006). In this context, previous scholars identified important non-market approaches to mitigate institutional voids, such as the coupling of firm and state interest to generate institutional change and progress (Child and Tse 2001). Lepoutre and Valente (2012) explore the role of CSR in contexts marred by institutional voids and how concerned firms are able to develop responsible business practices. In this context, Amaeshi et al. (2016) reveal how corporate ethics coupled with the corporate need for social legitimacy are important drivers behind CSR activities in institutionally weak contexts.

The UN considers CSR as a developmental tool that can be employed to redress various social inequalities (Ghosh and Chakraborti 2010). Firms seek to portray themselves as socially responsible entities (Alvarado-Herrera et al. 2017) and attempt to achieve this by aligning their corporate image with social causes (Luo and Bhattacharya 2006). Barros et al. (2014) find that CSR is motivated by economic rather than environmental concerns. Stakeholders are interested in social sustainability due to the potential alignment with a firm's environmental and economic interests (Galuppo et al. 2014). Nurunnabi et al. (2020) argue that SDGs implicitly rely on CSR implementation, and thus, CSR can become an effective tool to achieve SDGs. Chintrakarn et al. (2017) find that firms that are geographically closer to each other tend to have similar CSR programs due to similarities in their social milieu. Extending Chintrakarn et al. (2017), it is reasonable to expect that CSR programs with national scope will also tend to be similar due to commonalities in the nation's social fabric.

Abdelhalim and Eldin (2019) argue that the absence of a formal institutional structure that facilitates state participation in promoting CSR leads to the non-alignment of SDGs with CSR. ElAlfy et al. (2020) observe that legislative influence on CSR could incentivize the private sector to implement strategic CSR. Further, Hoque et al. (2018) find that in a voluntary CSR regime, there is a propensity to employ CSR as a public relations (image building) exercise rather than address social well-being. This implies that mandating 
CSR would enable closer linkage between CSR and SDGs. Thus, we propose that CSR programs should explicitly consider alignment with SDGs. We anticipate that such a focus is contingent upon appropriate institutional structures and that a mandatory CSR regime, such as the one launched in India, can facilitate this.

Schedule VII of Section 135 in the Indian Companies Act, 2013 (henceforth Act) mandates CSR across industries. The Act sets out specific criteria to identify firms that are included within the scope of the CSR mandate. The Act further requires that CSR disclosures form part of the annual audited accounts and prescribes the disclosure format. We consider that this provides an institutional infrastructure that is conducive to aligning firm-level CSR with national SDG targets. In the sub-section that follows, we discuss the links between the CSR mandate in the Act and the SDGs.

\section{Indian Companies Act (2013) and SDGs}

India is the first country to mandate CSR across industries, vide the Companies Act (2013). Though there has been an increase in CSR activity in India since the enactment of the Act (CRISIL 2020), we do not find many serious attempts to integrate CSR activities with SDGs. Hence, we explore the linkages between CSR activities and SDG outcomes with reference to the Act and then examine the CSR-SDG linkages within the specific context of the COVID-19 pandemic. Mulky (2017) dichotomizes the SDGs into those that are only achievable by governments and those that are achievable jointly by governments and business firms. He observes that SDG 1, SDG 10, SDG 13 and SDG 17 can only be achieved by governments, while SDGs 2-9, SDGs 10-12 and SDGs 14-16 ideally require partnerships between governments and firms.

In a sample of Indian companies, Mulky (2017) found that 10 of the 17 SDGs were addressed by the CSR programs of firms. Similarly, Mitra and Chatterjee (2020) posit that development projects with goals that are expected to perpetuate will, at some point, contribute to the achievement of SDGs. Figure 1 shows how the Companies Act (2013) links CSR with SDGs. SDGs 10 and 17 are missing from Figure 1 as the problem of inequality (SDG 10) cuts across sectors beyond the purview of business and "global partnerships" (SDG 17) and is generally beyond the scope of domestic companies ${ }^{3}$.

Poddar and Narula (2020) map CSR expenditure by Indian firms in 2017-2018 to SDGs and show that most of the CSR expenditure and projects pertained to SDG 4 (Quality Education). We present their findings in Figure 2 in order to illustrate an interesting trend that Poddar and Narula (2020) do not comment on. Figure 2 shows that, in most cases, the number of projects exceeded investment. There could be a variety of reasons for this. This could be because compliance with the statute was the overriding concern for these companies and so many companies spent the bare minimum required by the statute. Or, possibly, these firms may have estimated that addressing multiple goals in a "limited" manner carried a more favorable message to stakeholders. A lack of integration between CSR initiatives and the organization's mission (Delai and Takahashi 2011) could also explain the phenomenon of the number of projects exceeding expenditure. A further possible explanation is provided by Lu et al. (2021), who suggest that firms may sacrifice altruistic objectives of CSR for profit motives by selecting low-cost CSR projects. 


\section{Mapping SDGs To Schedule VII CSR Activities, Company's Act 2013}

Eradicating hunger, poverty and malnutrition, promoting preventive healthcare and sanitation - [SDG1-3]

Ensuring environmental sustainability, ecological balance, protection of flora and fauna, animal welfare, agro-forestry, conservation of natural resources and maintaining quality of soil, air and water, including contribution to the Clean Ganga Fund set-up by the National Government for rejuvenation of river Ganga [SDGs 6, 7, 9, 12-15]

Promoting education, special education and employment enhancing vocational skills especially among children, women, elderly, and differently abled and livelihood enhancement projects - [SDG4]

Contributions/ funds to technology incubators located within academic institutions, approved by the National Government - [SDG4]

Promoting gender equality,
empowering women, setting up
homes and hostels for women and
orphans; setting up old age homes,
day care centers; other facilities for
senior citizens and measures for
reducing inequalities amongst
socially and economically
backward groups- [SDG5]

Rural development projects [SDG8]

Slum development [SDG11]

Measures benefiting armed forces veterans, war widows and their Dependents [SDG16]
Training to promote rural sports, nationally recognized sports, paraOlympic \& Olympic sports [SDG16]

Figure 1. Mapping SDGs with CSR under the Indian Companies Act (2013). Source: Adapted from Mitra and Chatterjee (2020).

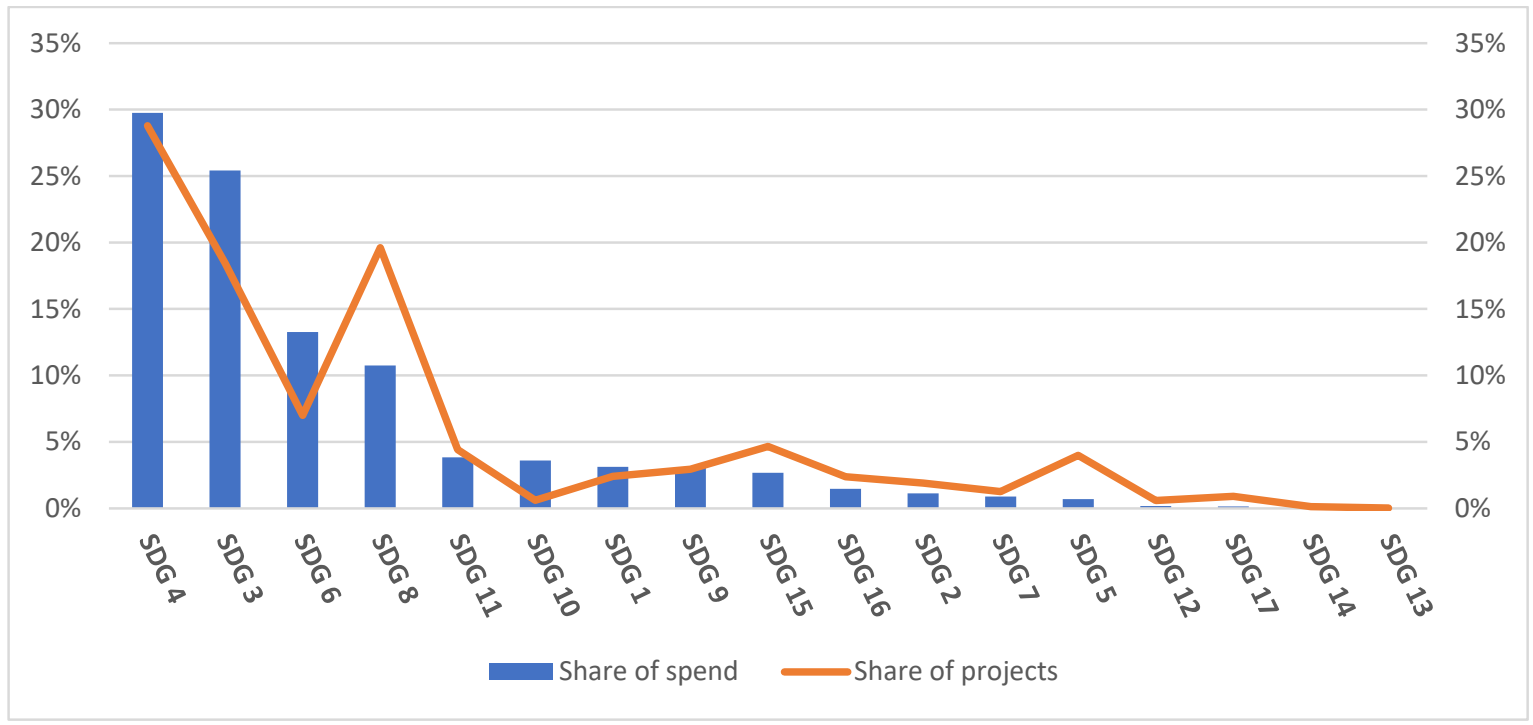

Figure 2. CSR expenditure and projects of Indian firms mapped to SDGs.

In a recent report, CRISIL shows that over the period 2015-2019, the top three areas of intervention by Indian CSR (in terms of both the number of projects and financial 
outlays) were education, health and rural development. The approximate increases in CSR expenditure between 2015 and 2019 were: education, 83\%; health, 68\%; and rural development, 38\% (CRISIL 2020). These trends were supported by a study conducted by the Indian Institute of Corporate Affairs (IICA) to determine SDGs impacted by CSR projects that focus on COVID-19. They report that SDG $3(79 \%)$ was amongst the most addressed SDGs by Indian CSR projects related to COVID-19 (IICA 2020). However, despite the attention to health and well-being, the pandemic has highlighted shortcomings in extant infrastructure and deliverables ${ }^{4}$.

Lu et al. (2021) observe that CSR may not achieve SDGs due to a variety of reasons. They imply that firms may limit their CSR to projects that address only a few SDGs, thus leading to a lack of progress on the other SDGs. Additionally, Lu et al. (2021) also posit that greenwashing, attempts to shield social irresponsibility and differences in the approach of national governments towards CSR could result in the non-achievement of SDGs through CSR. A closer scrutiny of the factors identified by Lu et al. (2021) shows that these are likely to be more prevalent in a voluntary CSR regime than in a mandatory CSR regime.

We argue that achieving effective integration and synergy between CSR and SDGs requires creating an overarching national and regional institutional architecture, ensuring quicker and more robust outcomes. Our argument is supported by calls from Abdelhalim and Eldin (2019) and ElAlfy et al. (2020) for an institutional framework and legislative impact on CSR in expectation that such a framework will attenuate the alignment of CSR and SDG objectives. Firstly, mandatory CSR disclosures (e.g., the Indian model) requiring the inclusion of financial metrics to measure performance against budget may lead to the incorporation of CSR into business plans and audited financials. The increased transparency and resultant investor interest might lead companies to eschew projects that do not contribute towards SDG targets. Secondly, companies may choose to be strategic and innovative by engaging in projects not undertaken by their competitors. The resultant diversity in CSR projects might lead to multiple SDGs being addressed simultaneously (thus mitigating one of Lu et al.'s (2021) factors that hinder CSR-SDG alignment). Since CSR is dependent on stakeholder support (Bulgacov et al. 2015), logically firms will undertake projects that address stakeholder concerns. Arguably, these concerns will metamorphose post-COVID-19 and reflect in future CSR programs and consequently impact the SDGs.

Here, we also suggest that the prescriptive nature of the Indian CSR legislation will help achieve SDG targets better than a voluntary CSR regime. Governments can specify CSR interventions, thus channeling firm resources to align CSR with SDG objectives. Local communities and other stakeholders may be more appreciative of CSR initiatives by firms in the region than government projects. The cumulative effect of similar projects carried out by companies in different parts of the country could lead to the speedier achievement of SDG targets.

\section{Linking CSR with SDGs: Devising Strategies and Actions in the Post-Pandemic World}

As stated in the preceding narrative, prior to the pandemic, the SDGs with their current focus on principles of people and planet seem to have been appropriate. We suggest that, in the new normal (post-pandemic), the SDGs within those principles ought to be re-prioritized and better integrated with CSR strategies and actions. For example, over the period 2014-2018, in India, 68\% of the total CSR expenditure was on SDGs 1-6 (People), and only 9\% was on SDGs 12-15 (Planet) (MCA 2018). Mitra and Chatterjee (2020) point out that, "in India, at the time of mandating CSR, environment and socio-economic parameters needed the most attention" (p. 385). From a firm's perspective, this focus makes sense, as outcomes are more tangible in socio-economic projects than those focusing on environmental stewardship. Stakeholders would most likely respond to outcomes that are tangible in the short term. Moreover, SDGs 1-6 as related to people and society are often viewed as prerogatives of the state (and public action). However, we argue that this ought to be seriously re-considered in the context of the current pandemic. 
In a post-COVID-19 world, we argue that the focus on SDGs 1-6 might be even more pertinent, but they ought to be reprioritized so that socio-economic recovery from the pandemic is more inclusive, equitable and rapid. As Broom and Willmer (2020) observed, COVID-19 caused an adverse effect on SDG programs and may have set back their achievement by many years. In that case, despite their linkages with each other, we argue that the world needs to focus on those SDGs that will prevent (or at least mitigate) the debilitating effects of bio-medical disasters such as the current pandemic. Our schema calls for a lesser focus on environmental SDGs. While not discounting the pain and chaos of natural disasters or climate change, we are optimistic that the positive impact COVID-19 has had on air and water quality (Zambrano-Monserrate et al. 2020; Bao and Zhang 2020) will continue and spill over to other environmental factors. We also presume that there will be significant positive environmental changes due to attitudinal and behavioral changes in society at large. Further, in concordance with extant forecasts (Mukherjee 2020; Shingal 2020; Veeramani 2020; Ray 2020), we expect a global reduction in commuting and traffic, including tourism (Gössling et al. 2020) post-COVID-19. Moreover, a healthy population can contribute to faster economic and social recovery in the wake of any natural or anthropogenic disasters.

Thus, we argue that, for the foreseeable future, resources ought to be directed towards "People centric" goals. Specifically, we suggest that Goals 3, 6, 5 and 4 (in that order) ${ }^{5}$ be given priority. Without undermining the importance of Goals 1 and 2, we contend that the fulfilment of Goals 3, 6, 5 and 4 will have a direct and positive bearing on Goals 1 and 2 . Our suggestions find support in the results of the Sustainable Development Report (Sachs et al. 2019) and the most recent literature, which discuss the impact of COVID-19 on SDGs (Shulla et al. 2021) and the implications of not achieving the SDGs (Leal Filho et al. 2020).

We resort to the project report by Sachs et al. (2019) on the status of the achievement of SDGs in various countries to develop our arguments. The report, as summarized in Table 1, considers 193 countries and classifies them according to the extent of SDG achievement. The report adopts a four-fold categorization ${ }^{6}$ of SDG achievement status, and shows that SDG 1 is the most commonly achieved goal (19\% of countries in the green category), while SDG 2 is the least achieved ( $60 \%$ of countries in the red category).

Table 1. Global status in achievement of SDGs (\% of target).

\begin{tabular}{|c|c|c|c|c|}
\hline & $\begin{array}{l}\quad \text { Red } \\
\text { Major Challenges } \\
\text { (Higher \% Is Bad) }\end{array}$ & $\begin{array}{c}\text { Orange } \\
\text { Challenges Remain } \\
\text { (Higher\% Is Bad) }\end{array}$ & $\begin{array}{c}\text { Yellow } \\
\text { Significant Challenges } \\
\text { (Higher \% Is Bad) }\end{array}$ & $\begin{array}{c}\text { Green } \\
\text { Goal Achievement } \\
\text { (Higher \% Is Good) }\end{array}$ \\
\hline SDG 1 & 24 & 14 & 26 & 19 \\
\hline SDG 2 & 60 & 33 & 1 & 0 \\
\hline SDG 3 & 54 & 24 & 14 & 4 \\
\hline SDG 4 & 26 & 27 & 37 & 5 \\
\hline SDG 5 & 37 & 45 & 13 & 1 \\
\hline SDG 6 & 41 & 34 & 20 & 1 \\
\hline SDG 7 & 32 & 16 & 37 & 14 \\
\hline SDG 8 & 31 & 39 & 19 & 1 \\
\hline SDG 9 & 56 & 37 & 6 & 1 \\
\hline SDG 10 & 44 & 21 & 14 & 4 \\
\hline SDG 11 & 22 & 45 & 26 & 1 \\
\hline SDG 12 & 22 & 25 & 34 & 15 \\
\hline SDG 13 & 34 & 25 & 34 & 7 \\
\hline SDG 14 & 26 & 39 & 11 & 0 \\
\hline SDG 15 & 11 & 51 & 31 & 3 \\
\hline SDG 16 & 56 & 22 & 11 & 2 \\
\hline SDG 17 & 15 & 31 & 41 & 6 \\
\hline
\end{tabular}


Sachs et al. (2019) bifurcate the 193 countries into 36 OECD and 157 non-OECD countries. We compared OECD countries and non-OECD countries and found that, with respect to SDGs 1-11, non-OECD countries performed worse than OECD countries. This could be because OECD countries tend to have better governance systems than non-OECD countries. Thus, it would seem that non-OECD countries need to strengthen their efforts more towards achieving SDGs than OECD countries. In this respect, linking SDGs to mandatory CSR in non-OECD countries might bring CSR programs under international spotlight and drive improvements in governance, which will inevitably lead to improved CSR and consequently the achievement of SDG targets.

In the next sub-section, since our paper proposes that the Indian model of mandated CSR is probably best suited to the achievement of SDGs, we present a brief assessment of India's achievement of SDGs in comparison to other BRICS nations ${ }^{7}$. The relative importance of these nations to the global economy (see footnote 3 ) and consequently the SDGs justifies employing them for this purpose.

As seen in Table 2 (Panel A), it may be difficult for India to attain those targets, having achieved only $53 \%$ of the 17 SDGs. Panel B of Table 2 shows the achievement status of the SDGs that this paper focuses on. Panel B clearly demonstrates that these SDGs require greater focus post-COVID-19. This is particularly true of SDG 3 , which is in the red category in all countries, except China. India, in particular, appears to be facing a steep challenge, with none of the focus SDGs appearing in either the yellow or green categories.

Table 2. Status of SDG achievement by BRICS nations.

\begin{tabular}{|c|c|c|c|c|c|}
\hline Category & Brazil & $\begin{array}{c}\text { Russian } \\
\text { Federation }\end{array}$ & India & China & South Africa \\
\hline \multicolumn{6}{|c|}{ Panel A: Achievement status of 17 SDGs } \\
\hline Red-Major Challenges & $24 \%$ & $24 \%$ & $53 \%$ & $24 \%$ & $41 \%$ \\
\hline Orange-Significant Challenges & $59 \%$ & $41 \%$ & $24 \%$ & $59 \%$ & $47 \%$ \\
\hline Yellow-Challenges Remain & $12 \%$ & $29 \%$ & $24 \%$ & $6 \%$ & $6 \%$ \\
\hline Green-Goal Achievement & $6 \%$ & $6 \%$ & $0 \%$ & $12 \%$ & $6 \%$ \\
\hline \multicolumn{6}{|c|}{ Panel B: Achievement status of focus SDGs } \\
\hline Red-Major Challenges & SDG 3 & SDG 3 & SDG $3,5,6$ & & SDG 3 \\
\hline Orange-Significant Challenges & SDG $4,5,6$ & SDG 5 & SDG4 & SDG $3,5,6$ & SDG 4,6 \\
\hline Yellow-Challenges Remain & & SDG 4,6 & & & \\
\hline Green-Goal Achievement & & & & SDG4 & \\
\hline
\end{tabular}

Source: Adapted from: Sachs et al. (2019).

To further elaborate, we advocate primary focus on SDG 3 (Good Health and WellBeing). The global spending on healthcare, pre-pandemic, was estimated to be $10 \%$ of global GDP (Shibli 2020). We analyzed Human Development Index (HDI) data from the UN Human Development Reports and observed that over the period 2014-2019, India's HDI improved the most among the BRICS nations ${ }^{8}$. Nevertheless, as discussed earlier, significant gaps in accessing healthcare facilities have been widely reported during the first and second waves of the ongoing COVID-19 pandemic. While adequate healthcare facilities and frontline healthcare workers are a pre-requisite to avoid any pandemic, the current situation is further exacerbated by the dearth of trained healthcare personnel, particularly in low- and middle-income countries (Shibli 2020). Nicola et al. (2020) comment that healthcare and pharmaceutical sectors face unprecedented upheavals resulting from the pandemic.

With this in mind, we have explored whether the CSR expenditure of the Indian companies under the mandatory CSR regime has any linkages with the SDGs, particularly those dealing with improving the status of development sectors, such as education, healthcare, water and sanitation (Appendix B). We collated the data on India's CSR expenditure for the period 2014-2020, thus effectively capturing the mandatory CSR regime. It may be 
observed that over the period 2014-2020, Indian CSR has invested mostly in education projects (5-year average of approximately $38 \%$ ). Over the same period, firms spent approximately INR 40 million ${ }^{9}$ (5-year average) on SDGs 1, 2, 3 and 6, together. Further analysis shows that of the INR 40 million, approximately $66 \%$ was invested in healthcare (see Appendix B). In light of the harrowing effects of the second wave of the pandemic and bearing in mind the risks of future outbreaks, it is obvious that the skew towards the education sector ought to be redressed. This makes a strong case for SDG 3 (good health and well-being) to receive utmost priority post COVID-19.

SDG 6 (clean water and sanitation) is closely linked to SDG 3. A UN Policy Brief (UN 2020a) states that access to clean water is a pre-requisite to prevent or control a pandemic. For example, in the current pandemic, clean water is considered to be the most critical resource required for handwashing. Access to clean water also enhances sanitation and consequently curtails the spread of infections and waterborne diseases. Ironically, four years since its launch, this SDG looks unachievable, as per a recent report by UNESCO (UN 2019), which found that billions of people were lacking safe water and sanitation. The report also stated that unsafe drinking water and sanitation accounted for $100 \%$ of "infections with soil transmitted helminths" (UN 2019, p. 8). Significantly, as shown in Appendix B, over the five-year period, only $15 \%$ of national CSR expenditure has been directed towards SDG 6. This highlights the need for an institutional intervention to channelize CSR towards this SDG. Considering the obvious connection between good health and access to clean water in sanitary surroundings, we maintain that SDG 6 should share top priority with SDG 3.

Based on the Indian scenario, we identify SDG 5 (gender equality) to be the next priority in a developing country context. The UN policy brief on the impact of COVID-19 on women notes that gender equality is far from being achieved globally. While Venugopalan et al. (2021) state that entrepreneurship ought to be promoted to achieve women's empowerment, Bonin et al. (2021) observe that COVID-19 has had a profound impact on women entrepreneurs. Broom and Willmer (2020) observe that women constituted more than $2 / 3$ of illiterate adults in 2018. Alon et al. (2020) argue that the recession caused by the pandemic affects the socio-economic fabric and cuts across demographics, with a huge impact on the economy and society, especially on women. Alon et al. (2020) also observe that not only are women disadvantaged due to their role as caregivers in the family, but they are also subject to socio-cultural biases, among several other deprivations, preventing employment. Such resistance would be much reduced if gender-phobic stereotypes are dismantled and equality promoted. In developing markets, almost $70 \%$ of employed women work in the informal economy (UN 2020b). These are the first jobs to suffer during times of crisis. Resuscitating those income avenues would help only until the next crisis. Our call to prioritize SDG 5 is also borne out by the Indian data presented in Appendix B, which shows that over the period 2014-2019, on average, only $2.74 \%$ of national CSR funds were spent on this SDG. Hence, we consider gender equality (SDG 5) as the next important priority in order to ensure that women are better protected against similar situations in the future.

Kane (1995) demonstrates that education has a positive impact on recognizing gender inequalities. The role of education in creating awareness and bringing about change in society qualifies education (SDG 4) as the next priority. Murphy-Graham and Lloyd (2016) state that educating girls is an extremely effective force that can hasten the transformation of society. Thus, we infer and argue that good quality education leads to greater gender equality and thus SDG 4 and SDG 5 are inextricably linked, implying that these SDGs should be accorded equal priority. However, since the fruits of education take longer to manifest, we suggest that gender equality (SDG 5) is a higher priority in the immediate aftermath of COVID-19.

As the world increasingly goes online, e-waste ${ }^{10}$ is likely to witness an exponential growth. For instance, the exposure of healthcare workers to infected patients increases their chances of contracting diseases. While policies and protocols are urgently required 
to mitigate this risk, the capability of healthcare workers to provide remote assistance to needy patients should also be enhanced. Such remote assistance will most likely use significant volumes of electronic and digital equipment, which will, in turn, generate more e-waste. Therefore, our focus on the selected SDGs notwithstanding, we are cognizant of the need to accord e-waste management the next highest priority. Tjoa and Tjoa (2016) identify the significant role information and communication technologies (ICT) play in achieving the SDGs, particularly SDG 4. However, the proliferation of and dependency on ICT involve a cost (Hilty and Aebischer 2015). While recognizing the importance of ICT and enabled services in influencing every SDG, we do not dwell on this topic. However, in no way does this imply a detraction of its salience in this debate. Rather, by not elaborating upon the obvious, we acknowledge it as a priority regardless of the SDG that is focused on.

In summary, our views concur with Shibli (2020), who underscores that in a postpandemic scenario, a few SDG targets gain greater priority than others. This perhaps gives the world an opportunity to prioritize health-related SDGs over others. Hakovirta and Denuwara (2020) also put forth similar arguments for a fundamental change in the structure of SDGs and contend that health ought to be the fourth pillar of the SDGs. We do not envisage a realignment between pillars; rather, we posit that the relative importance of goals within categories and the targets ought to change post-COVID-19.

Our views are equally supported by research related to institutional voids that calls for more attention to be paid to the relation between corporate activities and context (Bruton et al. 2021; Mair and Marti 2009), which requires corporate approaches to be aligned with context-related developmental priorities. Lack of effective state action does not have to deter companies in their CSR efforts; in fact, such absence of local and national governments creates spaces for creativity and entrepreneurship. Creating concerted approaches for companies with disparate understanding and interests regarding CSR is a major undertaking for all stakeholders. However, engaging companies to lend their support for combined attempts that promote health, sanitation, gender equality and education will contribute to CSR effectiveness and reduce risks that company efforts are perceived as illegitimate.

\section{Conclusions and Imperatives for Research, Policies and Actions}

Strengthening the linkages between CSR and SDGs along with reprioritizing the SDGs poses a major challenge in the emerging global context in terms of searching for an efficient institutional architecture that mobilizes the huge financial investments required for achieving the goals within their original deadlines as envisaged by Agenda 2030. As our analysis based on the Indian case indicates, a mandated CSR regime offers a sustainable solution by synchronizing the efforts of companies and governments in achieving the SDGs. The imperative for such an institutional mechanism is justified, as it can overcome the twin problems of market failure or state failure that are widely held as the roadblocks for the lack of progress in achieving the SDGs. Shibli (2020) also argues that a partnership between governments, private enterprises and civil society is imperative if pandemics, such as COVID-19, are to be dealt with effectively and efficiently. Additionally, Jayaprakash and Pillai (2018) argue that corporate social responsibility programs of private firms can enhance efforts to achieve SDG targets.

SDGs are likely to be as relevant in a post-COVID-19 world as they were before the pandemic. However, the advent of a new normal will in all probability Crequires new responses, strategies and coordinated actions. We argue that while SDGs remain relevant, the priority of issues addressed by them will require significant reorientation to reflect the new normal. While some prior research calls for structural changes to the SDGs, we do not advocate over-hauling the framework and including new goals. We argue that re-prioritizing the existing goals and targets through better linkages and synergy with CSR will effectively meet the demands of the post-COVID-19 world.

We propose that corporate entities assume a more proactive role in reorienting their CSR initiatives towards achieving the SDG targets in the post-pandemic global context. Using India as an example, we opine that a mandatory CSR regime might help guide 
a firm's resources towards achieving SDGs. Further, we consider that firms, through their CSR activities, are perhaps better placed to help nations and national governments achieve SDGs through their CSR. Therein lies a limitation of this paper: the realignment we espouse may not occur in a voluntary CSR regime. Our proposition is contingent on a well-designed and articulated institutional architecture, including legal provisioning and governmental regulations. A further limitation is the assumption of governments agreeing on the priorities suggested here. There are apprehensions that the environmental improvements as reported during the pandemic period will be short-lived, and so, our arguments are contingent on a significant assumption that the altered lifestyles seen during the outbreak of COVID-19 will continue.

Limitations notwithstanding, our work entails various future directions and implications: as our research shows, CSR represents great opportunities to fill existent institutional voids and install structurally transformative systems that function beyond fixing temporary pains and problems. For this, however, governments need to provide proper directions regarding overarching CSR goals that relate to critical areas of societal concern. This would also require some coordination efforts regarding CSR and a more structured approach to address identified areas of interest. On a company level, this necessitates CSR strategies that are aligned with strategic development goals of local and national governments. In India, as shown in our research, CSR is already mandatory and firms either "comply or explain" their approaches. There remains a need, though, to assure that companies spend their money on socially responsible activities aligned with public interests. Currently, no mechanisms exist that ensure that CSR activities fit development endeavors and that company efforts fit the context. This implies equally that companies need to enhance their CSR processes and acknowledge their contextual nature for initiatives to be effective.

Author Contributions: Conceptualization: R.N., P.K.V. \& B.L.B.; Literature Review: R.N., B.L.B. \& P.K.V.; Methodology: R.N. \& P.K.V.; Validation: R.N.; Original draft preparation: R.N.; Review: R.N., P.K.V. \& B.L.B.; Discussion: R.N., P.K.V. \& B.L.B. All authors have read and agreed to the published version of the manuscript.

Funding: This research received no external funding.

Institutional Review Board Statement: Not applicable.

Informed Consent Statement: We express our consent to publish the article and confirm that the manuscript has been submitted solely to this journal and is not published, in press, or submitted elsewhere.

Data Availability Statement: Data and materials will be shared after the publication of the manuscript upon request.

Acknowledgments: We acknowledge the anonymous reviewers following the acceptance of publication of the manuscript.

Conflicts of Interest: We declare that there are no competing interests. 


\section{Appendix A}

GOAL 1: No Poverty

GOAL 2: Zero Hunger

GOAL 3: Good Health and Well-being

GOAL 4: Quality Education

GOAL 5: Gender Equality

GOAL 6: Clean Water and Sanitation

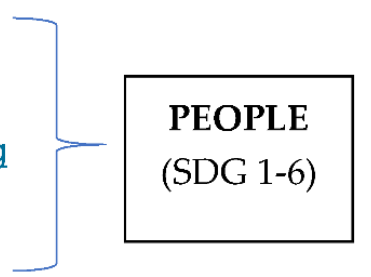

GOAL 7: Affordable and Clean Energy

GOAL 8: Decent Work and Economic Growth

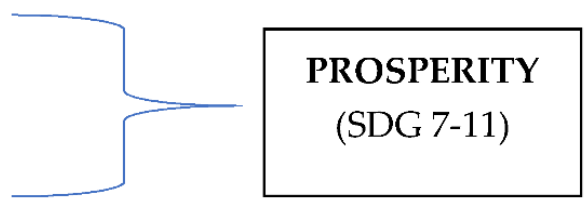

GOAL 9: Industry, Innovation and Infrastructure

GOAL 10: Reduced Inequality

GOAL 11: Sustainable Cities and Communities

\author{
GOAL 12: Responsible Consumption and Production \\ GOAL 13: Climate Action \\ GOAL 14: Life Below Water \\ GOAL 15: Life on Land
}

PLANET

(SDG 12-15)

GOAL 16: Peace and Justice Strong Institutions

PEACE

GOAL 17: Partnerships to achieve the Goal

PARTNESRHIPS

Appendix B. CSR Expenditure by Indian Firms: 2014-2019

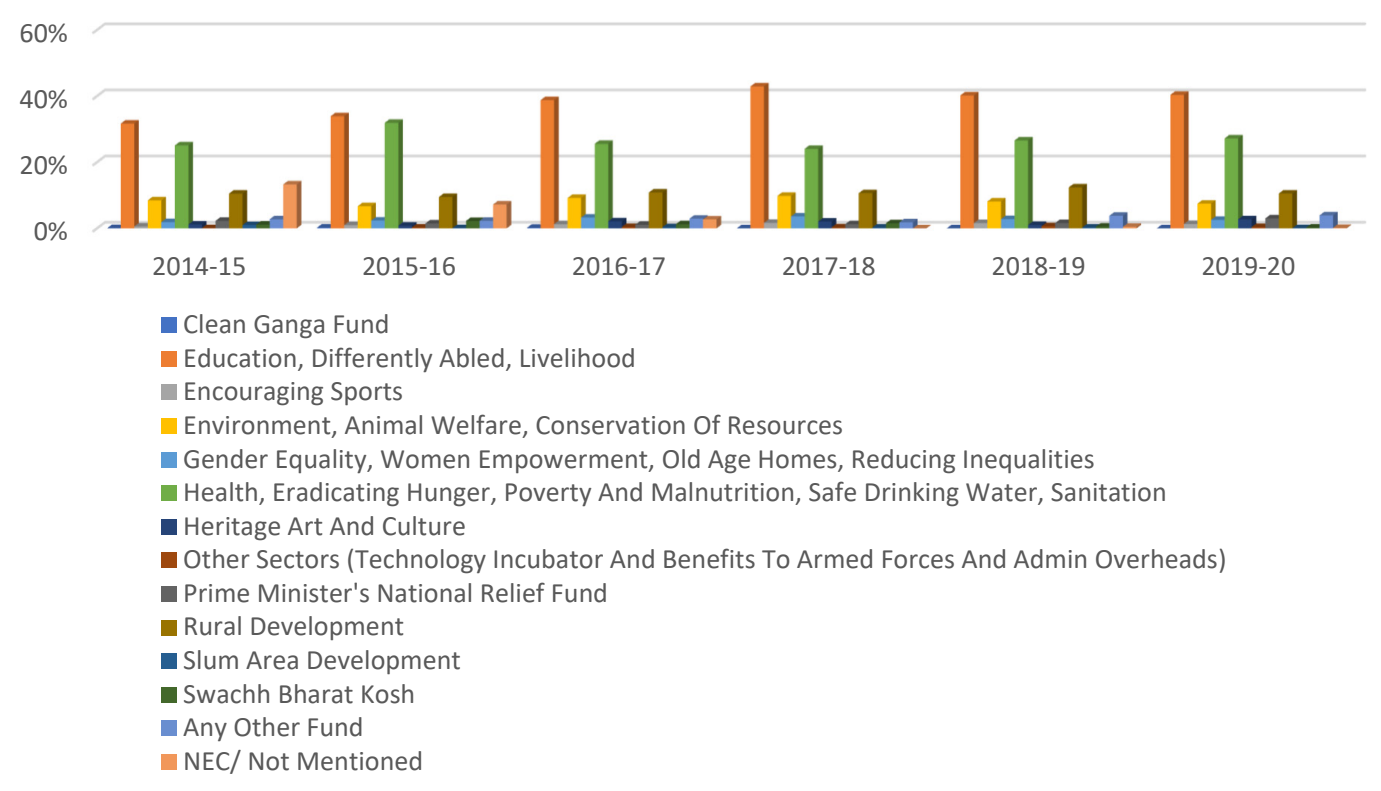

Source: National CSR Portal, https://www.csr.gov.in/developmentlist.php, accessed on 7 May 2021. 


\begin{tabular}{|c|c|c|c|c|c|c|c|}
\hline \multirow{2}{*}{$\begin{array}{l}\text { Breakdown of } \\
\text { Item } 6\end{array}$} & \multicolumn{6}{|c|}{ CSR Expenditure by Indian Firms (Amounts in INR Crores. 1 Crore $=10$ Million) $($ USD $=$ INR 73.74) } & \multirow{2}{*}{$\begin{array}{c}5 \text { Year } \\
\text { Average }\end{array}$} \\
\hline & 2014-2015 & 2015-2016 & 2016-2017 & 2017-2018 & 2018-2019 & $2019=2020$ & \\
\hline $\begin{array}{c}\text { SDG } 1 \text { and } \\
\text { 2-Eradicating } \\
\text { Hunger, Poverty } \\
\text { and Malnutrition }\end{array}$ & 274.70 & 1252.08 & 606.55 & 654.80 & 1090.27 & 818.29 & $20 \%$ \\
\hline SDG 3-Healthcare & 1847.74 & 2569.43 & 2491.09 & 2210.77 & 3216.41 & 3438.27 & $66 \%$ \\
\hline $\begin{array}{l}\text { SDG 6-Safe } \\
\text { Drinking Water } \\
\text { and Sanitation }\end{array}$ & 403.49 & 811.96 & 569.50 & 473.50 & 652.56 & 608.49 & $15 \%$ \\
\hline
\end{tabular}

Source: National CSR Portal, https:/ / www.csr.gov.in/developmentlist.php, accessed on 7 May 2021.

\section{Notes}

1 https:/ / sustainabledevelopment.un.org/?menu=1300 (accessed on 24 September 2021).

$2 \quad \mathrm{USD}=$ INR 73.74.

3 SDG 10 targets reducing income inequality within and among countries. Arguably, this can be achieved mainly through nationallevel policies and coordinated efforts of inter-governmental agencies, treaties and initiatives. SDG 17 refers to cooperation between nations and governments rather than companies.

4 Our observation about extant infrastructure is based on various media that highlighted the dire situation in India (shortage of hospital beds and oxygen). Data of 2015-2019 provide context to the thrust of the paper that despite the attention given to health, even until just prior to the pandemic, the sector was ill equipped to adequately cope with the demands placed on it by the pandemic.

5 SDG 1: No Poverty; SDG 2: Zero Hunger; SDG 3: Good Health and Well-Being; SDG 4: Quality Education; SDG 5: Gender Equality; SDG 6: Clean Water and Sanitation

6 Classification code Grey, representing countries that do not meet the thresholds set for inclusion in the analysis, is not included in Table 1. For a detailed description of the methodology used by Sachs et al. (2019), see: https:/ /www.sdgindex.org/reports/susta inable-development-report-2019/ (accessed on 24 September 2021).

7 BRICS (Brazil, Russia, India, China and South Africa) is a grouping of the world's leading emerging economies. In 2019, globally they represented $41 \%$ of population, 33\% of GDP, 19\% of exports and 16\% of imports (http://infobrics.org/post/31036/\#: : text=The $\% 20$ share $\% 20$ of $\% 20$ BRICS $\% 20$ in, share $\% 20$ of $\% 20$ the $\% 20$ five $\% 20 \%$ D1\%81ountries) (accessed on 24 September 2021).

8 Since the CSR mandate was effective from 1 April 2014, the period 2014-2019 was studied to judge the possible impact of the mandate. For comparative purposes, we also measured the HDI value change over the period 2010-2013 and found that India performed on par with the other countries. Thus, we arrive at a reasonable supposition that the CSR mandate played a role in channelling CSR towards projects that led to an improvement in the HDI of India.

$9 \quad \mathrm{USD}-\mathrm{INR}=73.74$.

10 The Council of European Union (2012) defines electronic waste or e-waste as any end-of-life (EoL) piece of equipment that depends on electric currents or electromagnetic fields to function properly and includes all components, sub-assemblies and consumables that constituted the product when discarded. E-waste is generated when electronic and electrical equipment become unfit for their initially planned use or have elapsed the expiry date. Examples of e-wastes are: computers, mainframes, servers, monitors, compact discs (CDs), calculators, fax machines, scanners, printers, copiers, battery cells, cellular phones, transceivers, TVs, iPods, medical apparatus, washing machines, refrigerators and air conditioners.

\section{References}

Abdelhalim, Khalid, and Amani Gamal Eldin. 2019. Can CSR help achieve sustainable development? Applying a new assessment model to CSR cases from Egypt. International Journal of Sociology and Social Policy 39: 773-95. [CrossRef]

Alon, Titan, Matthias Doepke, Jane Olmstead-Rumsey, and Michèle Tertilt Alon. 2020. The Impact of the Coronavirus Pandemic on Gender Equality. COVID Economics, Centre for Economic Policy Research 4: 62-85.

Alvarado-Herrera, Alejandro, Enrique Bigne, Joaquin Aldas-Manzano, and Rafael Curras-Perez. 2017. A scale for measuring consumer perceptions of corporate social responsibility following the sustainable development paradigm. Journal of Business Ethics 140: 243-62. [CrossRef]

Amaeshi, Kenneth, Emmanuel Adegbite, and Tazeeb Rajwani. 2016. Corporate social responsibility in challenging and non-enabling institutional contexts: Do institutional voids matter? Journal of Business Ethics 134: 135-53. [CrossRef]

Banerjee, Sudeshna Ghosh, Jennifer M. Oetzel, and Rupa Ranganathan. 2006. Private provision of infrastructure in emerging markets: Do institutions matter? Development Policy Review 24: 175-202. [CrossRef]

Bao, Rui, and Acheng Zhang. 2020. Does lockdown reduce air pollution? Evidence from 44 cities in Northern China. Science of the Total Environment 731: 139052. [CrossRef] 
Barros, Denise Franca, Joao Felipe Rammelt Sauerbronn, and Alessandra Mello da Costa. 2014. Corporate sustainability discourses in a Brazilian business magazine. Social Responsibility Journal 10: 4-20. [CrossRef]

Bhowmick, Soumya. 2020. COVID-19 'Infecting' Sustainable Development Goals. Asia Times Financial. Available online: https: / / asiatimes.com/2020/04/COVID-19-infecting-sustainable-development-goals / (accessed on 7 May 2020).

Bonin, Sandrine, Wafa Singh, Veena Suresh, Tarek Rashed, Kuiljeit Uppaal, Rajiv Nair, and Rao R. Bhavani. 2021. A priority action roadmap for women's economic empowerment (PARWEE) amid Covid-19: A co-creation approach. International Journal of Gender and Women's Empowerment 13: 142-61. [CrossRef]

Broom, Fiona, and Gareth Willmer. 2020. SDG Setback ‘Tremendous' as COVID-19 Accelerates Slide. SciDevNet. Available online: https://www.scidev.net/global/sdgs/feature/sdg-setback-tremendous-as-COVID-19-accelerates-slide.html?_cf_chl_jschl_ tk__=5b61fd3d24c3a2fd7b97b52914fd7088abdd33fe-1592806897-0-AbGT2X0xHZvRldgIuoe5UKtoUeEjzMJIlsreDfaeNVkhw pe91t-SMR-RBTDWKDxbcBtYqF3e8dvtJghvZlLCaNY-7Kdv5qZBmV207mW-gl1B19QI9t18tTxkLROAwkZLhwMQo918rBlVN VMQnCQtnQfrJk-g55LWlq39rTP--BV_caHLDJP37Nx9i_w4t5cAf0xC6RNtKx3k8kz51VUz1KECpYvO6NXNxlMbUlfGAYX3G AiV9V8DIoHHhKqZNXj09sl-o179ED1JixQQFwzBST0s48suabYIy1mxuG2Pd5-rZ5dNE5yocazQos5h_osX4KUFDn611q9kp96 tN2ErhnklyW_u6PahnVmQ-ZHLQNPSQS6tKZg1k5fW8_3dJQWyTw (accessed on 3 June 2020).

Bruton, Garry D., Shaker A. Zahra, Andrew H. Van de Ven, and Michael A. Hitt. 2021. Indigenous theory uses, abuses, and future. Journal of Management Studies. Available online: https:/ / onlinelibrary.wiley.com/doi/abs/10.1111/joms.12755 (accessed on 7 May 2020).

Bulgacov, Sergio, Maria Paola Ometto, and Márcia Ramos May. 2015. Differences in sustainability practices and stakeholder involvement. Social Responsibility Journal 11: 149-60. [CrossRef]

Child, John, and David K. Tse. 2001. China's transition and its implications for international business. Journal of International Business Studies 32: 5-21. [CrossRef]

Chintrakarn, Pandej, Pornsit Jiraporn, Napatsorn Jiraporn, and Travis Davidson. 2017. Estimating the effect of corporate social responsibility on firm value using geographic identification. Asia-Pacific Journal of Financial Studies 46: 276-304. [CrossRef]

Cohen, Erik, and Scott A. Cohen. 2015. Beyond Eurocentrism in tourism: A paradigm shift to mobilities. Tourism Recreation Research 40: 157-68. [CrossRef]

CRISIL. 2020. Doing Good in Bad Times. Available online: https://www.crisil.com/content/dam/crisil/our-analysis/reports/corpo rate/documents/2020/06/doing-good-in-bad-times.pdf (accessed on 19 September 2020).

Delai, Ivete, and Sérgio Takahashi. 2011. Sustainability measurement system: A reference model proposal. Social Responsibility Journal 7: 438-71. [CrossRef]

Doh, Jonathan, Suzana Rodrigues, Ayse Saka-Helmhout, and Mona Makhija. 2017. International business responses to institutional voids. Journal of International Business Studies 48: 293-307. [CrossRef]

ElAlfy, Amr, Nicholas Palaschuk, Dina El-Bassiouny, Jeffrey Wilson, and Olaf Weber. 2020. Scoping the Evolution of Corporate Social Responsibility (CSR) Research in the Sustainable Development Goals (SDGs) Era. Sustainability 12: 5544. [CrossRef]

Galuppo, Laura, Mara Gorli, Giuseppe Scaratti, and Cesare Kaneklin. 2014. Building social sustainability: Multi-stakeholder processes and conflict management. Social Responsibility Journal 10: 685-701. [CrossRef]

Ghosh, Anupam, and Chhanda Chakraborti. 2010. Corporate Social Responsibility: A Developmental Tool for India. IUP Journal of Corporate Governance 9: 40-56.

Gössling, Stefan, Daniel Scott, and C. Michael Hall. 2020. Pandemics, tourism and global change: A rapid assessment of COVID-19. Journal of Sustainable Tourism 29: 1-20. [CrossRef]

Hakovirta, Marko, and Navodya Denuwara. 2020. How COVID-19 Redefines the Concept of Sustainability. Sustainability 12: 3727. [CrossRef]

He, Hongwei, and Lloyd Harris. 2020. The impact of COVID-19 pandemic on corporate social responsibility and marketing philosophy. Journal of Business Research 116: 176-82. [CrossRef] [PubMed]

Hilty, Lorenz M., and Bernard Aebischer. 2015. ICT for Sustainability: An Emerging Research Field. In ICT Innovations for Sustainability. Advances in Intelligent Systems and Computing. Edited by Lorenz M. Hilty and Bernard Aebischer. Cham: Springer, vol. 310.

Hoque, Nazamul, Abdul Rahim Abdul Rahman, Rafiqul Islam Molla, Abu Hanifa Md. Noman, and Mohammad Zahid Hossain Bhuiyan. 2018. Is corporate social responsibility pursuing pristine business goals for sustainable development? Corporate Social Responsibility and Environmental Management 25: 1130-42. [CrossRef]

IICA (Indian Institute of Corporate Affairs). 2020. Business Response to COVID-19 through CSR. Available online: https:/ iica.nic.in/ images/CSR_COVID_Publication.pdf (accessed on 18 October 2020).

Jayaprakash, Parvathi, and R. Radhakrishna Pillai. 2018. Role of Indian ICT Organisations in Realising Sustainable Development Goals through Corporate Social Engagement. In Digital India. Advances in Theory and Practice of Emerging Markets. Edited by Arpan Kumar Kar and Shuchi Sinha M. P. Gupta. Cham: Springer. [CrossRef]

Kane, Emily W. 1995. Education and Beliefs about Gender Inequality. Social Problems 32: 74-90. [CrossRef]

Palepu, Krishna G., and Tarun Khanna. 1998. Institutional voids and policy challenges in emerging markets. The Brown Journal of World Affairs 5: 71-78.

Kopnina, Helen. 2016. The victims of unsustainability: A challenge to sustainable development goals. International Journal of Sustainable Development and World Ecology 2: 113-21. [CrossRef] 
Kumar, Sanjiv, Neeta Kumar, and Saxena Vivekadhish. 2016. Millennium Development Goals (MDGs) to Sustainable Development Goals (SDGs): Addressing Unfinished Agenda and Strengthening Sustainable Development and Partnership. Indian Journal of Community Medicine 41: 1-4. [CrossRef] [PubMed]

Leal Filho, Walter, Franziska Wolf, Amanda Lange Salvia, Ali Beynaghi, Kalterina Shulla, Marina Kovaleva, and Claudio R. P. Vasconcelos. 2020. Heading towards an unsustainable world: Some of the implications of not achieving the SDGs. Discover Sustainability 1: 2. [CrossRef]

Lepoutre, Jan MWN, and Michael Valente. 2012. Fools breaking out: The role of symbolic and material immunity in explaining institutional nonconformity. Academy of Management Journal 55: 285-313. [CrossRef]

Luo, Xueming, and Chitra Bhanu Bhattacharya. 2006. Corporate social responsibility, customer and satisfaction, and market value. Journal of Marketing 70: 1-18. [CrossRef]

Lu, Joanne. 2020. What Will COVID-19 Do to the Sustainable Development Goals? Available online: https://www.undispatch.com/w hat-will-COVID-19-do-to-the-sustainable-development-goals / (accessed on 22 May 2020).

Lu, Jintao, Mengshang Liang, Chong Zhang, Dan Rong, Hailing Guan, Kristina Mazeikaite, and Justas Streimikis. 2021. Assessment of corporate social responsibility by addressing sustainable development goals. Corporate Social Responsibility and Environmental Management 28: 686-703. [CrossRef]

Mair, Johanna, and Ignasi Marti. 2009. Entrepreneurship in and around institutional voids: A case study from Bangladesh. Journal of Business Venturing 24: 419-35. [CrossRef]

MCA (Ministry of Corporate Affairs). 2018. Report of the High Level Committee on Corporate Social Responsibility. Available online: https:/ / www.mca.gov.in/Ministry/pdf/CSRHLC_13092019.pdf (accessed on 15 June 2020).

Mitra, Nayan, and Bhaskar Chatterjee. 2020. India's Contribution to the Sustainable Development Goals (SDGs) with Respect to the CSR Mandate in the Companies Act, 2013. In The Future of the UN Sustainable Development Goals, CSR, Sustainability, Ethics $\mathcal{E}$ Governance. Edited by Samuel O. Idowu, René Schmidpeter and Liangrong Zu. Cham: Springer, ISBN 978-3-030-21153-0. [CrossRef]

Mukherjee, Sacchidananda. 2020. COVID-19: How to Minimize Uncertainties, Increase Confidence and Achieve Economic Stability in India. In COVID-19: Challenges for the Indian Economy - Trade and Foreign Policy Effects. Edited by AIC-EEPC. New Delhi: ASEAN-India Centre (AIC)—Engineering Export Promotion Council of India (EEPC).

Mulky, Avinash. 2017. Are CSR Activities Directed towards Sustainable Development Goals? A Study in India. Paper presented at International OFEL Conference on Governance, Management and Entrepreneurship, Dubrovnik, Croatia, April 7-8; pp. 266-79. Available online: https:/ / search.proquest.com/docview/1945555843?accountid=38661 (accessed on 21 October 2020).

Murphy-Graham, Erin, and Cynthia Lloyd. 2016. Empowering adolescent girls in developing countries: The potential role of education. Policy Futures in Education 14: 556-77. [CrossRef]

Nicola, Maria, Zaid Alsafib, Catrin Sohrabic, Ahmed Kerwand, Ahmed Al-Jabird, Christos Iosifidisc, Maliha Aghae, and Riaz Aghaf. 2020. The socio-economic implications of the coronavirus pandemic (COVID-19): A review. International Journal of Surgery 78: 185-93. [CrossRef]

Nurunnabi, Mohammad, Javier Esquer, Nora Munguia, David Zepeda, Rafael Perez, and Luis Velazquez. 2020. Reaching the sustainable development goals 2030: Energy efficiency as approach to corporate social responsibility (CSR). GeoJournal 85: 363-74. [CrossRef]

Osuji, Emeka, and Stanley Emife Nwani. 2020. Achieving Sustainable Development Goals: Does Government Expenditure Framework Matter? International Journal of Management, Economics and Social Sciences 9: 131-60. [CrossRef]

Pieterse, Jan Nederveen. 1996. The development of development theory: Towards critical globalism. Review of International Political Economy 3: 541-64. [CrossRef]

Poddar, Anushree, and Sapna A. Narula. 2020. A Study of Corporate Social Responsibility (CSR) and Sustainable Development Goal (SDG) Practices of the States in India. In Mandated Corporate Social Responsibility, CSR, Sustainability, Ethics E Governance. Edited by Nayan Mitra and Rene Schmidpeter. Cham: Springer. [CrossRef]

Ray, R. Sumantra. 2020. A Glimpse of Hope from Global Investors amidst COVID-19. In COVID-19: Challenges for the Indian EconomyTrade and Foreign Policy Effects. Edited by AIC-EEPC. New Delhi: ASEAN-India Centre (AIC)—Engineering Export Promotion Council of India (EEPC).

Regmi, Kapil Dev, and Pierre Walter. 2017. Modernisation Theory, ecotourism policy, and sustainable development for poor countries of the global south: Perspectives from Nepal. International Journal of Sustainable Development and World Ecology 24: 1-14. [CrossRef]

Sabu, Jithin. 2020. South Asia's prospects of achieving the SDGs in view of the COVID-19 pandemic. Trade Insight 16: 9-11.

Sachs, Jeffrey, Guido Schmidt-Traub, Christian Kroll, Guillaume Lafortune, and Grayson Fuller. 2019. Sustainable Development Report 2019. New York: Bertelsmann Stiftung and Sustainable Development Solutions Network (SDSN).

Shah, Ruchika. 2020. In the Post COVOD-19 Era, Am Opportunity to Build Back Better. Available online: https:/ /www.forbesindia.co m/article/coronavirus/how-has-COVID-19-affected-indias-progress-with-sdgs/59899/1 (accessed on 7 June 2020).

Shibli, Abdullah. 2020. Sustainable Development Goals: What to Salvage from COVID-19. Inter Press Service. Available online: http:/ / www.ipsnews.net/2020/05/sustainable-development-goals-salvage-COVID-19/ (accessed on 18 June 2020).

Shingal, Anirudh. 2020. Responding to the COVID-19 Crisis: Policy Priorities for India. In COVID-19: Challenges for the Indian Economy-Trade and Foreign Policy Effects. Edited by AIC-EEPC. New Delhi: ASEAN-India Centre (AIC)—Engineering Export Promotion Council of India (EEPC). 
Shulla, Kalterina, Bernd-Friedrich Voigt, Stefan Cibian, Giuseppe Scandone, Edna Martinez, Filip Nelkovski, and Pourya Salehi. 2021. Effects of COVID-19 on the Sustainable Development Goals (SDGs). Discover Sustainability 2: 15. [CrossRef]

Singh, Preet Deep. 2020. MCA Allows COVID-19 under CSR Expenditure: Can/Will Startup Get Money? Invest India: National Investment Promotion and Facilitation Agency. Available online: https://www.investindia.gov.in/team-india-blogs/mca-allows -COVID-19-under-csr-expenditure-can-will-startup-get-money (accessed on 16 August 2020).

Solberg, Erna, and Nana Addo Dankwa Akufo-Addo. 2020. Why We Can't Lose Sight of the Sustainable Development Goals during Coronavirus. World Economic Forum. Available online: https://www.weforum.org/agenda/2020/04/coronavirus-pandemic-ef fect-sdg-un-progress (accessed on 25 May 2020).

Tsalis, Thomas A., Kyveli E. Malamateniou, Dimitrios Koulouriotis, and Ioannis E. Nikolaou. 2020. New challenges for corporate sustainability reporting: United Nations 2030 Agenda for sustainable development and the sustainable development goals. Corporate Social Responsibility and Environmental Management 27: 1617-29. [CrossRef]

The Council of European Union. 2012. Directive 2012/19/EU of the European Parliament and of the Council of 4 July 2012 on Waste Electrical and Electronic Equipment (WEEE) (Recast). Official Journal of the European Union L 197: 38-71. Available online: http:/ / eur-lex.europa.eu/legal-content/EN/TXT/PDF/?uri=CELEX:32012L0019\&from=EN (accessed on 24 September 2021).

Tjoa, A. Min, and Simon Tjoa. 2016. The Role of ICT to Achieve the UN Sustainable Development Goals (SDG). In ICT for Promoting Human Development and Protecting the Environment. WITFOR 2016. IFIP Advances in Information and Communication Technology. Edited by Francisco J. Mata and Ana Pont. Cham: Springer, vol. 481.

UN.org. 2019. Special Edition: Progress towards the Sustainable Development Goals Report of the Secretary General, Economic and Social Council, Advance Unedited Version. Available online: https://sustainabledevelopment.un.org/content/documents/2270 0E_2019_XXXX_Report_of_the_SG_on_the_progress_towards_the_SDGs_Special_Edition.pdf (accessed on 24 September 2021).

UN.org. 2020a. Policy Brief No. 78. Available online: https://www.un.org/development/desa/dpad/wp-content/uploads/sites/45 /publication/PB_78.pdf (accessed on 6 June 2020).

UN.org. 2020b. Policy Brief: The Impact of COVID-19 on Women, 9 April 2020. Available online: https://www.un.org/sites/un2.un. org/files/policy_brief_on_covid_impact_on_women_9_apr_2020_updated.pdf (accessed on 30 September 2020).

UN.org. 2020c. UN Launches COVID-19 Plan That Could Defeat the Virus and Build a Better World. Available online: https: //news.un.org/en/story/2020/03/1060702 (accessed on 8 May 2020).

UNDESA. 2020. Available online: https:/ / devpolicy.org/with-COVID-19-the-sdgs-are-even-more-important-20200616-2/ (accessed on 9 July 2020).

Veeramani, C. 2020. COVID-19 Pandemic: Implications for India's Exports and Global Value Chains. In COVID-19: Challenges for the Indian Economy - Trade and Foreign Policy Effects. Edited by AIC-EEPC. New Delhi: ASEAN-India Centre (AIC)—Engineering Export Promotion Council of India (EEPC).

Venugopalan, Murale, Bettina Lynda Bastian, and P. K. Viswanathan. 2021. The Role of Multi-Actor Engagement for Women's Empowerment and Entrepreneurship in Kerala, India. Administrative Sciences 11: 31. [CrossRef]

World Economic Forum. 2020. How Big Business Is Joining the Fight against COVID-19. Available online: https://www.weforum.org/ agenda/2020/03/big-business-joining-fight-against-coronavirus / (accessed on 30 May 2020).

Zambrano-Monserrate, Manuel A., María Alejandra Ruano, and Luis Sanchez-Alcalde. 2020. Indirect effects of COVID-19 on the environment. Science of the Total Environment 728: 138813. [CrossRef] [PubMed] 